\title{
The nutritional interrelationship between the growing and finishing phases in crossbred cattle raised in a tropical system
}

\author{
Ricardo Linhares Sampaio ${ }^{1}$ - Flávio Dutra de Resende ${ }^{2,3} \cdot$ Ricardo Andrade Reis $^{3}$. \\ Ivanna Moraes de Oliveira ${ }^{2}$ - Letícia Custódio ${ }^{3}$ - Rodolfo Maciel Fernandes ${ }^{3}$. \\ Raul Dirceu Pazdiora ${ }^{4} \cdot$ Gustavo Rezende Siqueira $^{2,3}$
}

Received: 2 September 2016 / Accepted: 19 April 2017 / Published online: 26 April 2017

(C) Springer Science+Business Media Dordrecht 2017

\begin{abstract}
This study evaluated the nutritional interrelationship between the growing and finishing phases of crossbred cattle in determining their performance. One hundred and eight animals were used (8 months old, body weight [BW] $211 \pm 20 \mathrm{~kg}$ ). During the dry season, the animals received one of the following supplements: a mineral plus urea supplement (ad libitum, MSD), a protein supplement (1 $\mathrm{g} / \mathrm{kg} \mathrm{BW}$ per day, PR1), or a protein-energy supplement (5 $\mathrm{g} / \mathrm{kg} \mathrm{BW}$ per day, $\mathrm{PE})$. During the rainy season, the animals received one of the following supplements: a mineral without urea supplement (ad libitum, MSR), a protein supplement ( $1 \mathrm{~g} / \mathrm{kg} \mathrm{BW}$ per day, PR2), or PE (5 g/kg BW per day). The experimental design was completely randomized using a $3 \times 3$ factorial scheme (for the rainy season) and a $3 \times 3 \times 2$ factorial scheme (for the finishing phase). The supplementation and finishing systems were considered to be the treatments, and the animals were considered to be the experimental units. Dry season supplementation did not affect the average daily gain (ADG) during the rainy season $(P=0.12)$ or the finishing phase $(P=0.73)$. An increase in the level of rainy season supplementation reduced ADG by $12 \%$ during the finishing phase $(P<0.06)$. Providing PE during the dry and rainy seasons led
\end{abstract}

Ivanna Moraes de Oliveira

imoraesdeoliveira@yahoo.com.br

1 Beef Tec-Tecnologia em Pecuária, Campo Grande, Mato Grosso do Sul 79020-122, Brazil

2 APTA-Agência Paulista de Tecnologia dos Agronegócios, Colina, São Paulo 14770-000, Brazil

3 UNESP-Univ. Estadual Paulista, Jaboticabal, São Paulo 14884-900, Brazil

4 UNIR-Fundação Universidade Federal de Rondônia, Rolim de Moura, Rondônia 78987-000, Brazil to the animals being slaughtered $17(P=0.06)$ and 30 $(P<0.01)$ days earlier, respectively. Our results indicate that supplementation during the dry season (under poor-quality pasture conditions) does not affect the performance during the rainy season or the finishing phase. Furthermore, while providing PE during the rainy season can reduce ADG during finishing, the higher BW at the beginning of the finishing phase is sufficient to reduce the time of the finishing period.

Keywords Body composition · Carcass · Intact male · Marandu grass

\section{Introduction}

The production of grazing animals plays a fundamental role in tropical regions because of the existence of large tracts of land and the possibility of sustainable production (Boval and Dixon 2012). Additionally, in light of the increasing world population (UNF 2015), the pressure of other crops for land, and the need to reduce greenhouse gas emissions (Oliveira Silva et al. 2016), the focus of the production of grazing animals should be on productivity and increased efficiency. However, the seasonality of tropical pasture production impairs the maintenance of the animal's growth curve. As a result, supplementation may be used to increase the efficiency of grazing systems throughout the year (Detmann et al. 2014).

The use of supplementation for pasture-fed animals has been evaluated in many tropical systems. The evaluation is typically performed at different time points within the growth curve of the animal during the year (Detmann et al. 2014; Moretti et al. 2013; Roth et al. 2013). However, in temperate production systems, a nutritional level during one part of the growth curve can influence subsequent phases (McCurdy et al. 2010), interfering with the growth rate, metabolism, 
and the deposition of tissues (Keogh et al. 2015; Sainz et al. 1995). However, we currently lack an understanding of how feeding during one phase of the growth curve influences the growth during other phases under tropical conditions. Thus, the effect of supplementation strategies during the growth phase and the effect of feeding during the growing phase on the finishing performance of the animals must be investigated. Within this context, the objective of this study was to understand the nutritional interrelationship between the growing and finishing phases in crossbred cattle.

\section{Material and methods}

\section{Experimental area and climate data}

The experiment was conducted in Colina, São Paulo, Brazil $\left(20^{\circ} 43^{\prime} 05^{\prime \prime} \mathrm{S}\right.$ and $\left.48^{\circ} 32^{\prime} 38^{\prime \prime} \mathrm{W}\right)$. The grazing area was composed of 54 ha of land and was divided into three rotational grazing systems. Each system consisted of a central square containing a water trough $(1500 \mathrm{~L})$ and several feed bunks (40 linear $\mathrm{cm} / \mathrm{animal}$ ). Each of these rotational grazing systems was then divided into six paddocks (3 ha each) containing Brachiaria brizantha cv. Marandu pasture. During the finishing phase, the animals were kept in the pasture or in an experimental feedlot. The confinement area consisted of 60 half-covered individual pens measuring $10 \mathrm{~m}^{2}$ with a feed bunk and water trough. The climate data are presented in Table 1.

\section{Experimental period}

The experimental period consisted of a growing phase and finishing phase. The growing phase was divided into a postweaning dry season $(6 / 6$ to $10 / 10 ; 126$ days) and a rainy season $(11 / 10$ to $20 / 06 ; 252$ days). The dry season was further divided into three grazing cycles of 42 days each ( 7 days of occupation and 35 days of rest). The rainy season was divided into nine grazing cycles of 28 days each ( 7 days of occupation and 21 days of rest). After the rainy season, animals were moved to the finishing phase, which occurred either in a pasture (grazing cycle of 42 days; 7 days of occupation and 35 days of rest) or in a feedlot. The animals were evaluated until they had reached a body weight (BW) of $500 \mathrm{~kg}$, upon which they were sent for slaughter. The animals were adapted to the experimental conditions for 10 days prior to the growing phase and for 21 days prior to the finishing phase.

\section{Treatments}

The following three levels of supplementation were evaluated during the dry season: a mineral supplement with urea ad libitum (called MSD), a protein supplement (provided in the amount of $1 \mathrm{~g} / \mathrm{kg} \mathrm{BW}$ per day, called PR1), or a proteinenergy supplement (provided in the amount of $5 \mathrm{~g} / \mathrm{kg} \mathrm{BW}$ per day, called PE). The following three levels of supplementation were used in the rainy season: a mineral supplement without urea ad libitum (called MSR), a protein supplement (provided in the amount of $1 \mathrm{~g} / \mathrm{kg} \mathrm{BW}$ per day, called PR2), and PE (provided in the amount of $5 \mathrm{~g} / \mathrm{kg} \mathrm{BW}$ per day). The supplements consisted of ground corn, cottonseed meal, citrus pulp, dicalcium phosphate, urea, and monensin sodium (Table 2).

During the growing phase, the supplements were provided daily at 8:00 AM. The amount of supplement was adjusted based on the mean BW and number of animals in each group. The animals were weighed at the end of each grazing cycle. The mineral supplement with or without urea was available in covered feed bunks and was replaced as necessary, allowing ad libitum intake.

After the growing phase, the animals were subjected to one of the two finishing systems, pasture or feedlot finishing. For pasture finishing, the animals received the same $\mathrm{PE}(5 \mathrm{~g} / \mathrm{kg} \mathrm{BW})$ provided during the dry and rainy seasons daily at 8:00 AM. The amount was adjusted based on the mean $\mathrm{BW}$ and number of animals in each group. The animals were weighed every 21 days. For feedlot finishing, corn silage was offered at a proportion of $500 \mathrm{~g} / \mathrm{kg}$ diet. The corn silage contained $77 \mathrm{~g} / \mathrm{kg}$ crude protein $(\mathrm{CP})$ and $589 \mathrm{~g} / \mathrm{kg}$ neutral detergent fibre. The composition of the concentrate in grammes per kilogramme was as follows: citrus pulp (527), soybean hull (250), 46\% soybean meal (38), 38\% cottonseed meal (115), minerals (41), and urea (30). The diet was formulated to provide an average daily gain (ADG) of $1.35 \mathrm{~kg}$ (NRC 1996). Feedlot-finished animals received a single meal in the morning at an amount that allowed ad libitum intake. Before offering the meal, leftovers were collected and weighed to control feed intake. The diet was adjusted to permit $5 \%$ leftovers.
Table 1 Climate data collected in the research unit during the experimental period

\begin{tabular}{llll}
\hline Item & $\begin{array}{l}\text { Dry season } \\
(06 / 06 \text { to } 10 / 10)\end{array}$ & $\begin{array}{l}\text { Rainy season } \\
(10 / 11 \text { to 06/20) }\end{array}$ & $\begin{array}{l}\text { Finishing phase } \\
(06 / 21 \text { up to reaching 500 kg) }\end{array}$ \\
\hline Average precipitation $(\mathrm{mm})$ & 16.6 & 138.0 & 144.6 \\
Average temperature $\left({ }^{\circ} \mathrm{C}\right)$ & 21.7 & 23.1 & 23.7 \\
\hline
\end{tabular}


Table 2 Nutrient level (dry matter basis) of the supplements fed to crossbred cattle during the dry season $(06 / 06$ to $10 / 10)$, the rainy season (10/11 to $06 / 20)$, and the pasture or feedlot finishing phases $(06 / 21$ up to reaching $500 \mathrm{~kg}$ )

\begin{tabular}{|c|c|c|c|c|c|c|c|c|}
\hline \multirow[t]{2}{*}{ Nutrient (g/kg dry matter) } & \multicolumn{3}{|c|}{ Dry season $^{\mathrm{a}}$} & \multicolumn{3}{|c|}{ Rainy season ${ }^{\mathrm{b}}$} & \multicolumn{2}{|c|}{ Feedlot finishing } \\
\hline & $\operatorname{MSD}^{\mathrm{c}}$ & PR1 & $\mathrm{PE}$ & $\mathrm{MSR}^{\mathrm{d}}$ & PR2 & $\mathrm{PE}$ & Concentrate & Total diet \\
\hline Crude protein & 888 & 565 & 278 & - & 333 & 278 & 223 & 148 \\
\hline Total digestible nutrients & - & - & 668 & - & - & 668 & 65 & 647 \\
\hline Non-protein nitrogen ${ }^{\mathrm{e}}$ & 888 & 361 & 102 & - & 144 & 102 & 87 & 42 \\
\hline Calcium & 84 & 73 & 26 & 163 & 86 & 26 & 22 & 13 \\
\hline Phosphorus & 42 & 17 & 6.7 & 84 & 22 & 6.7 & 4.7 & 3.2 \\
\hline $\begin{array}{l}\text { Monensin, } \mathrm{mg} / \mathrm{kg} \text { dry } \\
\text { matter }\end{array}$ & - & 222 & 89 & - & 222 & 89 & - & - \\
\hline
\end{tabular}

${ }^{\mathrm{a}} \mathrm{MSD}=$ mineral supplement with urea ad libitum; PR 1 = protein supplement offered at $1 \mathrm{~g} / \mathrm{kg}$ body weight (BW) per day; $\mathrm{PE}=$ energy-protein supplement offered at $5 \mathrm{~g} / \mathrm{kg} \mathrm{BW}$ per day

${ }^{\mathrm{b}} \mathrm{MSR}=$ mineral supplement without urea ad libitum; PR2 = protein supplement offered at $1 \mathrm{~g} / \mathrm{kg} \mathrm{BW}$ per day; PE $=$ energy-protein supplement offered at $5 \mathrm{~g} / \mathrm{kg} \mathrm{BW}$ per day

${ }^{\mathrm{c}}$ Composition of the mineral supplement with urea, in $\mathrm{g} / \mathrm{kg}$ : $\mathrm{Mg}$ 5, S 40, and $\mathrm{Na} \mathrm{100;} \mathrm{in} \mathrm{mg/kg:} \mathrm{Cu} \mathrm{520,} \mathrm{Mn} \mathrm{400,}$ Zn 1925, I 38, Co 30, and Se 10

${ }^{\mathrm{d}}$ Composition of the mineral supplement without urea, in $\mathrm{g} / \mathrm{kg}$ : $\mathrm{Mg} \mathrm{10}, \mathrm{S} 40$, and $\mathrm{Na} 130$; in $\mathrm{mg} / \mathrm{kg}$ : $\mathrm{Cu} 1350, \mathrm{Mn}$ 1040, Zn 5000, I 100, Co 80, and Se 26

${ }^{\mathrm{e}}$ Protein equivalent

\section{Experimental animals and treatment allocation}

One hundred and eight intact male $\mathrm{F}_{1}$ Angus/Nellore cattle with an initial mean age of 8 months and an initial mean BW of $211 \pm 20 \mathrm{~kg}$ were evaluated. At the beginning of the dry season, the 108 animals were randomly divided into three groups of 36 animals each and assigned to one of the three dry season treatments. After the dry season, each group of 36 animals was divided into three subgroups. The animals from each subgroup were randomly assigned to a rainy season treatment, grouped, and subjected to the same rotational grazing system. After the rainy season, each subgroup of 12 animals was divided into two new subgroups. These animals were randomly assigned to one of the two finishing systems and were then grouped and allocated to the rotational grazing system or individual pens (Table 3). For adjustment of the stocking rate in the paddocks, contemporary animals were used to balance forage offer between supplementations.

\section{Forage evaluation and bromatological analysis}

Forage availability was characterized by weekly samplings in the paddock of each rotational grazing system. The samples were collected on the day prior to animal rotation at six random sites at the entry of the paddocks. The direct sampling of a $1.0-\mathrm{m}^{2}$ square was used to determine forage availability. A $0.25-\mathrm{m}^{2}$ subsample was collected at the soil level at the centre of each site. This subsample was divided into leaf, stem, and dead materials, which were dried at $55{ }^{\circ} \mathrm{C}$ in a forced draft oven for $72 \mathrm{~h}$, ground through a mill (Thomas Model 4 Wiley, Thomas Scientific, Swedesboro, NJ, USA) using a 1-mm mesh sieve, and stored for further chemical analysis. Samples of the whole plant, leaves, diet, and leftovers were analysed for dry matter (DM, method 950.46), CP (method 928.080) (AOAC 1995), and lignin (Goering and Van Soest 1970) levels. The neutral detergent fibre and acid detergent fibre levels were determined as proposed by Robertson and Van Soest (1981).

Exploratory data analysis of the pastures was performed. No differences in quantitative or qualitative forage characteristics were observed between the pasture systems during the dry season, rainy season, or finishing phase $(P>0.10)$ (Table 4). This lack of difference confirms the similarity of the pasture conditions, ruling out any confounding effect and inferring that the performance responses are due to treatments.

\section{Performance}

During the growth phase, the animals were weighed after each pasture cycle in the morning without previous fasting. During the finishing phase, the animals were weighed every 21 days in the morning without previous fasting. The evaluations were based on ADG calculated as a function of the initial and final BW of the animals. During weighing, the animals were dewormed with $1 \%$ ivermectin (Ivomec, Merial, Paulínea, São Paulo, Brazil) at the beginning of the experiment, at the end of the dry season, and at the end of the rainy season. 
Table 3 Experimental design

\begin{tabular}{|c|c|c|c|}
\hline $\begin{array}{l}\text { Dry season } \\
(06 / 06 \text { to } 10 / 10) n=108\end{array}$ & $\begin{array}{l}\text { Rainy season } \\
(10 / 11 \text { to } 06 / 20) n=108\end{array}$ & $\begin{array}{l}\text { Finishing }(06 / 21 \mathrm{up} \text { to } \\
\text { reaching } 500 \mathrm{~kg}) n=108\end{array}$ & Slaughter $n=108$ \\
\hline \multirow[t]{6}{*}{$\operatorname{MSD} n=36$} & \multirow[t]{2}{*}{$\operatorname{MSR} n=12$} & Pasture $n=6$ & $n=6$ \\
\hline & & Feedlot $n=6$ & $n=6$ \\
\hline & \multirow[t]{2}{*}{$\mathrm{PR} 2 n=12$} & Pasture $n=6$ & $n=6$ \\
\hline & & Feedlot $n=6$ & $n=6$ \\
\hline & \multirow[t]{2}{*}{ PE $n=12$} & Pasture $n=6$ & $n=6$ \\
\hline & & Feedlot $n=6$ & $n=6$ \\
\hline \multirow[t]{6}{*}{ PR1 $n=36$} & \multirow[t]{2}{*}{$\operatorname{MSR} n=12$} & Pasture $n=6$ & $n=6$ \\
\hline & & Feedlot $n=6$ & $n=6$ \\
\hline & \multirow[t]{2}{*}{$\mathrm{PR} 2 n=12$} & Pasture $n=6$ & $n=6$ \\
\hline & & Feedlot $n=6$ & $n=6$ \\
\hline & \multirow[t]{2}{*}{$\mathrm{PE} n=12$} & Pasture $n=6$ & $n=6$ \\
\hline & & Feedlot $n=6$ & $n=6$ \\
\hline \multirow[t]{6}{*}{$\operatorname{PE} n=36$} & \multirow[t]{2}{*}{$\operatorname{MSR} n=12$} & Pasture $n=6$ & $n=6$ \\
\hline & & Feedlot $n=6$ & $n=6$ \\
\hline & \multirow[t]{2}{*}{ PR2 $n=12$} & Pasture $n=6$ & $n=6$ \\
\hline & & Feedlot $n=6$ & $n=6$ \\
\hline & \multirow[t]{2}{*}{ PE $n=12$} & Pasture $n=6$ & $n=6$ \\
\hline & & Feedlot $n=6$ & $n=6$ \\
\hline
\end{tabular}

MSD = mineral supplement with urea ad libitum. MSR = mineral supplement without urea ad libitum. PR1 = protein supplement offered at $1 \mathrm{~g} / \mathrm{kg}$ body weight $(\mathrm{BW})$ per day. $\mathrm{PR} 2$ = protein supplement offered at $1 \mathrm{~g} / \mathrm{kg} \mathrm{BW}$ per day. $\mathrm{PE}=$ energy-protein supplement offered at $5 \mathrm{~g} / \mathrm{kg} \mathrm{BW}$ per day

Table 4 Qualitative and quantitative characteristics of the Marandu pasture during the growing phase (first dry season post weaning and rainy season) and pasture finishing (second dry season and dry-rainy transition) of crossbred cattle

\begin{tabular}{|c|c|c|c|}
\hline Item & $\begin{array}{l}\text { Dry season } \\
(06 / 06 \text { to } 10 / 10)\end{array}$ & $\begin{array}{l}\text { Rainy season } \\
(10 / 11 \text { to } 06 / 20)\end{array}$ & $\begin{array}{l}\text { Finishing }(06 / 21 \text { up to } \\
\text { reaching } 500 \mathrm{~kg})\end{array}$ \\
\hline \multicolumn{4}{|l|}{ Qualitative (g/kg dry matter) } \\
\hline \multicolumn{4}{|l|}{ Whole plant } \\
\hline Dry matter & $743 \pm 15$ & $318 \pm 12$ & $543 \pm 29$ \\
\hline Crude protein & $24 \pm 0.9$ & $57 \pm 1.6$ & $41 \pm 1.2$ \\
\hline Neutral detergent fibre & $850 \pm 5.1$ & $792 \pm 3.5$ & $825 \pm 5.1$ \\
\hline Acid detergent fibre & $512 \pm 8.6$ & $437 \pm 5.1$ & $470 \pm 6.0$ \\
\hline Lignin & $98 \pm 3.1$ & $78 \pm 2.0$ & $90 \pm 3.3$ \\
\hline \multicolumn{4}{|l|}{ Leaf } \\
\hline Crude protein & $100 \pm 4.3$ & $100 \pm 1.7$ & $115 \pm 4.0$ \\
\hline Neutral detergent fibre & $789 \pm 4.5$ & $751 \pm 4.1$ & $737 \pm 7.7$ \\
\hline Acid detergent fibre & $315 \pm 7.2$ & $342 \pm 2.9$ & $323 \pm 5.8$ \\
\hline Lignin & $49 \pm 4.2$ & $54 \pm 2.3$ & $53 \pm 2.6$ \\
\hline \multicolumn{4}{|l|}{ Quantitative } \\
\hline Leaf $(\mathrm{g} / \mathrm{kg})$ & $37 \pm 8.2$ & $382 \pm 18$ & $171 \pm 22$ \\
\hline Stem $(g / k g)$ & $126 \pm 12$ & $293 \pm 13$ & $136 \pm 13$ \\
\hline Senescent material (g/kg) & $839 \pm 16$ & $332 \pm 23$ & $693 \pm 32$ \\
\hline Forage allowance (kg dry matter $/ 100 \mathrm{~kg}$ body weight) & $13 \pm 0.9$ & $14 \pm 0.3$ & $24 \pm 1.8$ \\
\hline Leaf allowance (kg dry matter/100 kg body weight) & $0.8 \pm 0.3$ & $4.1 \pm 0.5$ & $4.0 \pm 0.7$ \\
\hline Forage mass (ton of dry matter/ha) & $4.1 \pm 0.3$ & $6.1 \pm 0.2$ & $5.3 \pm 0.2$ \\
\hline
\end{tabular}




\section{Slaughter}

Once the animals had reached $500 \mathrm{~kg}$, they were slaughtered at a commercial slaughterhouse $(20 \mathrm{~km}$ from the research institution). The animals were fasted from solids and fluids for $16 \mathrm{~h}$, and the slaughter weight was determined. During slaughter, the liver and kidney-pelvicheart fat were weighed. The half-carcasses were also weighed to obtain the hot carcass weight, which was used to determine the dressing percentage. After chilling, the loin eye area and backfat thickness were measured in the left half-carcass in a section of the longissimus dorsi muscle between the 12th and 13th ribs (Cañeque and Sañudo 2005).

The carcass transfer was calculated using the following formula: Carcass transfer $=\left[\frac{(\text { final hot carcass weight-initial hot carcass weight })}{\text { final BW-initial BW }}\right]$ $\times 1000$. The portion corresponding to the 9 th, 10 th, and 11 th ribs (HH section) of the left half-carcass was extracted to determine the tissular and chemical composition of the carcass. This method was described by Hankins and Howe (1946). The following equations were used to calculate the tissular composition: muscle $=16.08+[0.80 \times(\%$ muscle in the HH section $)]$, adipose tissue $=3.54+[0.80 \times(\%$ fat in the $\mathrm{HH}$ section $)]$, and bone $=5.52+$ $[0.57 \times(\%$ bone in the $\mathrm{HH}$ section) $)]$. To determine the chemical composition, the $\mathrm{HH}$ section (muscle, fat, and bone) was ground and analysed using methods recommended by the AOAC (1990): moisture (method 950.46), CP (method 928.080), and ether extract (EE; method 960.39). The values obtained were used in the following equations: moisture $=14.90+$ $[0.78 \times(\%$ water in the $\mathrm{HH}$ section $)], \mathrm{CP}=5.98+$ $[0.66 \times(\% \mathrm{CP}$ in the $\mathrm{HH}$ section $)]$, and $\mathrm{EE}=2.82+$ $[0.7 \times(\% \mathrm{EE}$ in the $\mathrm{HH}$ section $)]$.

\section{Statistical analysis}

The experimental design was completely randomized considering the level of supplementation in dry season, rainy season, and finishing system as the treatments and the animals as repetition. During the growing phase, the data were analysed using three treatments for the dry season (three levels of supplementation) and a $3 \times 3$ factorial scheme for the rainy season (three levels of supplementation in the dry season and three levels in the rainy season). The data were analysed in a $3 \times 3 \times 2$ factorial scheme (three levels of supplementation in the dry season, three levels in the rainy season, and two finishing systems) to evaluate the effect of the growing phase on finishing phase. The data were analysed using the PROC MIXED procedure of the SAS version 9.1 (Statistical Analysis System Institute, Inc., Cary, NC, USA), and the means were obtained with LSmeans. The variables were compared using Tukey's test at the 10\% significance level.

\section{Results}

During the dry season, animals receiving MSD exhibited a negative ADG of $0.080 \mathrm{~kg}$. Animals that had been supplemented with PR1 and PE gained 0.050 and $0.140 \mathrm{~kg}$ per day, respectively $(P<0.01)$. During the rainy season, ADG increased with the nutritional level of the supplement. The ADG of animals receiving PR2 and PE was higher (23\% and $46 \%$, respectively) than that of animals receiving MSR $(P<0.01)$. During finishing, feedlot-finished animals obtained a $103 \%$ higher ADG than pasture-finished animals $(P<0.01)$ (Table 5).

Table 5 Performance of crossbred cattle raised on the Marandu pasture during the dry season (06/06 to 10/10), rainy season (10/11 to $06 / 20)$ and finished on the pasture or in the feedlot (06/21 up to reaching $500 \mathrm{~kg}$ )

\begin{tabular}{|c|c|c|c|c|c|c|c|c|c|c|c|c|c|c|}
\hline \multirow[t]{2}{*}{ Item } & \multicolumn{3}{|c|}{ Dry season $^{\mathrm{a}}$} & \multirow[t]{2}{*}{$\mathrm{SEM}^{\mathrm{c}}$} & \multirow{2}{*}{$\begin{array}{l}P \\
\text { value }\end{array}$} & \multicolumn{3}{|c|}{ Rainy season $^{\mathrm{b}}$} & \multirow[t]{2}{*}{$\mathrm{SEM}^{\mathrm{c}}$} & \multirow{2}{*}{$\begin{array}{l}P \\
\text { value }\end{array}$} & \multicolumn{2}{|l|}{ Finishing } & \multirow[t]{2}{*}{$\mathrm{SEM}^{\mathrm{c}}$} & \multirow{2}{*}{$\begin{array}{l}P \\
\text { value }\end{array}$} \\
\hline & MSD & PR1 & PE & & & MSR & PR2 & PE & & & Pasture $^{\mathrm{d}}$ & Feedlot & & \\
\hline $\begin{array}{l}\text { Initial body weight } \\
\quad(\mathrm{kg})\end{array}$ & $212^{\mathrm{a}}$ & $211^{\mathrm{a}}$ & $210^{\mathrm{a}}$ & 20 & 0.90 & $214^{\mathrm{x}}$ & $215^{\mathrm{x}}$ & $215^{\mathrm{x}}$ & 20 & 0.99 & 391 & 392 & 38 & 0.91 \\
\hline $\begin{array}{l}\text { Final body weight } \\
\quad(\mathrm{kg})\end{array}$ & $201^{\mathrm{b}}$ & $217^{\mathrm{a}}$ & $226^{\mathrm{a}}$ & 19 & $<0.01$ & $361^{\mathrm{z}}$ & $388^{\mathrm{y}}$ & $423^{x}$ & 36 & $<0.01$ & 502 & 499 & 16 & 0.26 \\
\hline $\begin{array}{l}\text { Average daily gain } \\
(\mathrm{kg})\end{array}$ & $-0.08^{\mathrm{c}}$ & $0.05^{\mathrm{b}}$ & $0.14^{\mathrm{a}}$ & 0.1 & $<0.01$ & $0.57^{\mathrm{z}}$ & $0.70^{\mathrm{y}}$ & $0.83^{\mathrm{x}}$ & 0.1 & $<0.01$ & 0.73 & 1.48 & 0.2 & $<0.01$ \\
\hline
\end{tabular}

Means in the same row followed by the same superscript letter in the dry season $(\mathrm{a}, \mathrm{b}, \mathrm{c})$ or in the rainy season $(\mathrm{x}, \mathrm{y}, \mathrm{z})$ do not differ from one another based on Tukey's test $(P>0.10)$

${ }^{\mathrm{a}} \mathrm{MSD}=$ mineral supplement with urea ad libitum; PR1 = protein supplement offered at $1 \mathrm{~g} / \mathrm{kg}$ body weight $(\mathrm{BW})$ per day; PE = energy-protein supplement offered at $5 \mathrm{~g} / \mathrm{kg}$ BW per day

${ }^{\mathrm{b}} \mathrm{MSR}=$ mineral supplement without urea ad libitum; PR2 = protein supplement offered at $1 \mathrm{~g} / \mathrm{kg} \mathrm{BW}$ per day; $\mathrm{PE}=$ energy-protein supplement offered at $5 \mathrm{~g} / \mathrm{kg} \mathrm{BW}$ per day

${ }^{\mathrm{c}} \mathrm{SEM}=$ standard error of the mean

${ }^{\mathrm{d}}$ Finishing on pasture with energy-protein supplement offered at $5 \mathrm{~g} / \mathrm{kg} \mathrm{BW}$ 
No interaction was observed between the supplementation strategies used during the dry and rainy seasons $(P=0.93)$. Similarly, there was no interaction between the supplementation strategies used during the growing phase and the finishing system $(P=0.53)$. During the rainy season, the ADG was not influenced by the supplementation provided during the dry season $(0.700 \mathrm{~kg}, P=0.12)$. However, at the beginning of the rainy season, animals that received PR1 and PE during the dry season were heavier (16 and $25 \mathrm{~kg}$, respectively) than animals fed MSD $(P<0.01)$. This difference only persisted in the rainy season for animals fed PE during the dry season. A BW difference of $16 \mathrm{~kg}$ at the end of the dry season for animals supplemented with PR1 decreased to $4 \mathrm{~kg}$ at the end of the rainy season (Table 6). Our evaluation of the influence of the nutritional strategies used during the growing phase on finishing showed that during finishing phase, the ADG was not affected by supplementation provided during the dry season $(P=0.73)$. In contrast, during the finishing phase, animals supplemented with $\mathrm{PE}$ during the rainy season gained $0.130 \mathrm{~kg}$ less per day than did animals fed MSR $(P=0.06)$.

Differences between supplementation strategies during the growing phase affected the amount of time to reach slaughter during the finishing phase $(P<0.10)$. This is an indirect effect, as it was a function of BW at the beginning of the finishing phase. At the beginning of the finishing phase, animals supplemented with PE during the dry season were $25 \mathrm{~kg}$ heavier than animals fed PR1 or MSD. As a result, they were slaughtered 17 days earlier than animals receiving MSD $(P=0.06)$. The time to reach a BW of $500 \mathrm{~kg}$ did not differ between animals that received MSD or PR1 during the dry season (mean $=133$ days, $P>0.10$ ). Regarding the rainy season, animals supplemented with PE were slaughtered 30 days earlier than those receiving MSR $(P<0.01)$. The time to reach a $\mathrm{BW}$ of $500 \mathrm{~kg}$ did not differ between animals that received MSR or PR2 during the rainy season (mean $=136$ days, $P>0.10)$. Feedlot-finished animals were heavier (differential of $17 \mathrm{~kg}$ ) and had a greater backfat

Table 6 Performance of crossbred cattle during the rainy season (10/11 to $06 / 20)$ according to dry season supplementation $(06 / 06$ to $10 / 10)$

\begin{tabular}{lcccccc}
\hline Item & \multicolumn{3}{c}{ Dry season supplement } & \multirow{2}{*}{$P$ value } & SEM $^{\mathrm{b}}$ \\
\cline { 2 - 5 } & MSD & PR1 & PE & & \\
\hline Initial body weight $(\mathrm{kg})$ & $201^{\mathrm{b}}$ & $217^{\mathrm{a}}$ & $226^{\mathrm{a}}$ & $<0.01$ & 20 \\
Final body weight $(\mathrm{kg})$ & $381^{\mathrm{b}}$ & $385^{\mathrm{b}}$ & $406^{\mathrm{a}}$ & $<0.01$ & 36 \\
Average daily gain $(\mathrm{kg})$ & 0.71 & 0.67 & 0.71 & 0.12 & 0.1 \\
\hline
\end{tabular}

Means in the same row followed by the same superscript letter do not differ from one another based on Tukey's test $(P>0.10)$

${ }^{\mathrm{a}} \mathrm{MSD}=$ mineral supplement with urea ad libitum; PR1 = protein supplement offered at $1 \mathrm{~g} / \mathrm{kg}$ body weight (BW) per day; $\mathrm{PE}=$ energy-protein supplement offered at $5 \mathrm{~g} / \mathrm{kg} \mathrm{BW}$ per day

${ }^{\mathrm{b}} \mathrm{SEM}=$ standard error of the mean thickness (differential of $2.40 \mathrm{~mm}$ ) than pasture-finished animals at the slaughter $(P<0.01)$ (Table 7). Overall, feedlotfinished animals were slaughtered 106 days earlier than pasture-finished animals ( 181 vs. 75 days, $P<0.01$ ).

With respect to carcass traits, dry season supplementation affected the proportion of kidney-pelvic-heart fat $(P=0.09)$. This proportion of fat was lower in animals receiving PE than in those that received MSD or PR1 (0.64 vs. $0.74 \%$ slaughter weight). The percentage of $\mathrm{CP}$ in the carcass was lower in animals that received PR1 during the dry season than in those that received MSD or PR1 (20.4 vs. $22.1 \%, P<0.01)$. In the rainy season, animals supplemented with PR2 had a higher dressing percentage than did animals that received MSR or PE (55.7 vs. $54.6 \%, P=0.09$ ). Pasture-finished animals presented higher CP $(11.3 \%$ more $)$ and lower EE $(55.2 \%$ less $)$ in the carcass than feedlot-finished animals $(P<0.01$, Table 8$)$.

\section{Discussion}

During the dry season, the ADG was not consistent with the level of supplementation used. The low proportion of leaves $(37 \mathrm{~g} / \mathrm{kg})$ and the qualitative characteristics of the pasture were likely not sufficient to ensure adequate performance of the animals. During the dry season, the CP content of the pasture was $24 \mathrm{~g} / \mathrm{kg} \mathrm{DM}$, which is well below the lower limit of $70 \mathrm{~g} /$ $\mathrm{kg}$ DM. Minson et al. (1990) suggested that a CP below this limit restricts the activity of ruminal microorganisms and compromises the rate of fibre degradation, consequently reducing feed intake. During the rainy season, the CP content $(57 \mathrm{~g} / \mathrm{kg}$ DM) was also below the lower limit of $70 \mathrm{~g} / \mathrm{kg}$, as was observed during the dry season. However, in contrast to the dry season, the leaf proportion in the canopy $(382 \mathrm{~g} / \mathrm{kg}$ ) promoted satisfactory performance. This satisfactory performance was observed even in animals receiving MSR. When there are a greater proportion of leaves, the animals can choose the parts of the plant with a higher nutritional value.

Once we had determined the nutritional interrelationship between growth and finishing, we evaluated the effect of one phase on the other. In other words, we determined whether the nutritional strategy of one phase positively or negatively affects the subsequent phases. Additionally, we evaluated the interaction between supplementation levels. This interaction is the result of the different effects of the supplements given during one phase on the supplements given during a subsequent phase.

Dry season supplementation strategies did not affect ADG during the subsequent phases (rainy season and finishing), regardless of the supplementation offered during the rainy season and the finishing phase. We expected differences in ADG during the subsequent phases because of the different dry season supplementation levels (Downs et al. 1998). However, in the present study, ADG during the dry season 
Table 7 Performance of crossbred cattle during finishing on pasture or in the feedlot ( $06 / 21$ up to reaching $500 \mathrm{~kg})$ according to dry season ( $06 / 06$ to $10 / 10)$ and rainy season (10/11 to $06 / 20)$ supplementation

\begin{tabular}{|c|c|c|c|c|c|c|c|c|c|}
\hline \multirow[t]{2}{*}{ Item } & \multicolumn{3}{|c|}{ Dry season supplement ${ }^{\mathrm{a}}$} & \multirow[t]{2}{*}{$P$ value } & \multicolumn{3}{|c|}{ Rainy season supplement ${ }^{\mathrm{b}}$} & \multirow[t]{2}{*}{$P$ value } & \multirow[t]{2}{*}{$\mathrm{SEM}^{\mathrm{c}}$} \\
\hline & MSD & PR1 & $\mathrm{PE}$ & & MSR & PR2 & $\mathrm{PE}$ & & \\
\hline Initial body weight $(\mathrm{kg})$ & $381^{\mathrm{b}}$ & $385^{\mathrm{ab}}$ & $406^{\mathrm{a}}$ & 0.02 & $361^{z}$ & $388^{\mathrm{y}}$ & $423^{x}$ & $<0.01$ & 38 \\
\hline Final body weight (kg) & 501 & 497 & 504 & 0.21 & 497 & 505 & 501 & 0.09 & 16 \\
\hline Average daily gain $(\mathrm{kg})$ & 1.05 & 1.01 & 1.04 & 0.73 & $1.09^{\times}$ & $1.04^{\mathrm{xy}}$ & $0.96^{\mathrm{y}}$ & 0.06 & 0.2 \\
\hline Days on feed & $135^{\mathrm{a}}$ & $131^{\mathrm{a}}$ & $118^{\mathrm{b}}$ & 0.06 & $141^{\mathrm{x}}$ & $131^{\mathrm{x}}$ & $112^{\mathrm{y}}$ & $<0.01$ & 29 \\
\hline
\end{tabular}

Means in the same row followed by the same superscript letter in the dry season $(\mathrm{a}, \mathrm{b}, \mathrm{c})$ or in the rainy season $(\mathrm{x}, \mathrm{y}, \mathrm{z})$ do not differ from one another based on Tukey's test $(P>0.10)$

${ }^{\mathrm{a}} \mathrm{MSD}=$ mineral supplement with urea ad libitum; PR1 = protein supplement offered at $1 \mathrm{~g} / \mathrm{kg}$ body weight $(\mathrm{BW})$ per day; PE = energy-protein supplement offered at $5 \mathrm{~g} / \mathrm{kg} \mathrm{BW}$ per day

${ }^{\mathrm{b}} \mathrm{MSR}=$ mineral supplement without urea ad libitum; PR2 = protein supplement offered at $1 \mathrm{~g} / \mathrm{kg} \mathrm{BW}$ per day; PE = energy-protein supplement offered at $5 \mathrm{~g} / \mathrm{kg} \mathrm{BW}$ per day

${ }^{\mathrm{c}} \mathrm{SEM}=$ standard error of the mean

was considerably lower than the ADG during the rainy season. This lower ADG led no effect on subsequent phases. Thus, under the condition of poor pasture quality, supplementation in the dry season had no effect on the performance during the rainy season and finishing phase. An ADG that was below $140 \mathrm{~g}$ for all dry season supplementation

Table 8 Carcass traits and the chemical and tissular composition of the carcass of crossbred cattle growing on pasture during the dry (06/06 to 10/10) and rainy $(10 / 11$ to $06 / 20)$ seasons and finished on pasture or in the feedlot $(06 / 21$ up to reaching $500 \mathrm{~kg})$

\begin{tabular}{|c|c|c|c|c|c|c|c|c|c|c|c|c|}
\hline \multirow[t]{2}{*}{ Item } & \multicolumn{3}{|c|}{ Dry season $^{\mathrm{a}}$} & \multirow[t]{2}{*}{$P$ value } & \multicolumn{3}{|c|}{ Rainy season ${ }^{\mathrm{b}}$} & \multirow[t]{2}{*}{$P$ value } & \multicolumn{2}{|l|}{ Finishing } & \multirow[t]{2}{*}{$P$ value } & \multirow[t]{2}{*}{ SEM } \\
\hline & MSD & $1 \mathrm{~g} / \mathrm{kgD}$ & $5 \mathrm{~g} / \mathrm{kg}$ & & MSR & PR2 & $5 \mathrm{~g} / \mathrm{kg}$ & & Pasture $^{\mathrm{c}}$ & Feedlot & & \\
\hline Slaughter weight ${ }^{\mathrm{e}}(\mathrm{kg})$ & 476 & 476 & 478 & 0.87 & 473 & 477 & 479 & 0.30 & 468 & 485 & $<0.01$ & 2.71 \\
\hline Dressing percent $(\%)^{\mathrm{f}}$ & 54.1 & 55.1 & 54.9 & 0.93 & $54.6^{\mathrm{x}}$ & $55.7^{\mathrm{y}}$ & $54.6^{\mathrm{x}}$ & 0.09 & 55.2 & 54.7 & 0.28 & 0.36 \\
\hline Liver $(\%)^{\mathrm{f}}$ & 1.33 & 1.29 & 1.29 & 0.25 & $1.36^{\mathrm{x}}$ & $1.31^{\mathrm{y}}$ & $1.25^{\mathrm{z}}$ & $<0.01$ & 1.24 & 1.36 & $<0.01$ & 0.02 \\
\hline Kidney-pelvic-heart fat $(\%)^{\mathrm{f}}$ & $0.76^{\mathrm{a}}$ & $0.71^{\mathrm{a}}$ & $0.64^{\mathrm{b}}$ & 0.09 & $0.78^{\mathrm{x}}$ & $0.68^{\mathrm{y}}$ & $0.64^{\mathrm{y}}$ & 0.04 & 0.45 & 0.90 & $<0.01$ & 0.04 \\
\hline Backfat thickness (mm) & 3.45 & 3.32 & 3.01 & 0.55 & 3.27 & 3.28 & 3.24 & 0.99 & 2.06 & 4.46 & $<0.01$ & 0.23 \\
\hline Loin eye area $\left(\mathrm{cm}^{2}\right)$ & 75 & 78 & 75 & 0.27 & 76 & 77 & 76 & 0.65 & 77 & 76 & 0.56 & 1.27 \\
\hline \multirow[t]{2}{*}{ Carcass transfer ${ }^{\mathrm{g}}$} & 722 & 744 & 690 & 0.22 & 710 & 730 & 710 & 0.76 & 730 & 710 & 0.55 & 1.02 \\
\hline & \multicolumn{12}{|c|}{ Tissular and chemical composition of the carcass (\%) } \\
\hline Muscle & 61.9 & 62.2 & 62.2 & 0.93 & 61.5 & 62.2 & 62.6 & 0.18 & 64.6 & 59.6 & $<0.01$ & 0.35 \\
\hline Fat & 21.3 & 20.7 & 20.8 & 0.86 & 21.8 & 20.9 & 20.2 & 0.10 & 17.6 & 25.4 & $<0.01$ & 0.45 \\
\hline Bone & 16.8 & 17.0 & 17.1 & 0.86 & 16.7 & 17.0 & 17.2 & 0.29 & 17.9 & 16.0 & $<0.01$ & 0.16 \\
\hline Crude protein & $21.8^{\mathrm{a}}$ & $20.4^{\mathrm{b}}$ & $22.4^{\mathrm{a}}$ & $<0.01$ & 21.1 & 20.6 & 21.9 & 0.11 & 22.7 & 20.4 & $<0.01$ & 0.22 \\
\hline Ether extract & 11.0 & 11.7 & 10.8 & 0.42 & 12.0 & 11.0 & 10.4 & 0.10 & 6.9 & 15.4 & $<0.01$ & 0.54 \\
\hline Moisture & 57.9 & 58.7 & 57.8 & 0.47 & 57.5 & 57.9 & 58.9 & 0.12 & 60.7 & 55.5 & $<0.01$ & 0.40 \\
\hline
\end{tabular}

Means in the same row followed by the same superscript letter in the dry season $(\mathrm{a}, \mathrm{b}, \mathrm{c})$ or in the rainy season $(\mathrm{x}, \mathrm{y}, \mathrm{z})$ do not differ from one another by the Tukey test $(P>0.10)$

${ }^{\mathrm{a}} \mathrm{MSD}=$ mineral supplement with urea ad libitum; PR1 = protein supplement offered at $1 \mathrm{~g} / \mathrm{kg}$ body weight $(\mathrm{BW})$ per day; PE = energy-protein supplement offered at $5 \mathrm{~g} / \mathrm{kg}$ BW per day

${ }^{\mathrm{b}} \mathrm{MSR}=$ mineral supplement without urea ad libitum; PR2 = protein supplement offered at $1 \mathrm{~g} / \mathrm{kg}$ BW per day; PE = energy-protein supplement offered at $5 \mathrm{~g} / \mathrm{kg} \mathrm{BW}$ per day

${ }^{\mathrm{c}}$ Finishing on pasture with energy-protein supplement offered at $5 \mathrm{~g} / \mathrm{kg} \mathrm{BW}$

${ }^{\mathrm{d}} \mathrm{SEM}=$ standard error of the mean

${ }^{\mathrm{e}} \mathrm{SW}$ : slaughter weight after fasting

${ }^{\mathrm{f}}$ Percentage of slaughter weight

${ }^{\mathrm{g}}$ Carcass transfer: relationship between carcass gain and body weight gain, in $\mathrm{g}$ carcass $/ \mathrm{kg} \mathrm{BW}$ 
treatments indicates limited animal performance. This ADG was far below the $0.300 \mathrm{~kg}$ /day value considered after a moderate feeding restriction (Hornick et al. 2000). This limited performance may be due to the characteristics of the pasture, as discussed above. It is also possible that compensatory gain had occurred in all of the animals, particularly during the rainy season. In this season, a high ADG was observed, particularly during the early periods. In general, when growth is delayed due to some type of limitation, the animal is able to recover by growing at a faster rate (Carstens 1995; Ryan 1990). This is the result of metabolic adaptations at the time of limitation, associated with a reduction in the size and activity of gastrointestinal tract organs (Carstens et al. 1991; Sainz et al. 1995). Thus, an increase in nutrient availability, in conjunction with lower maintenance energy, would increase the rate of weight gain.

During the finishing phase, supplementation given during the rainy season did affect the ADG. Animals that received PE during the rainy season gained $0.130 \mathrm{~kg}$ less per day than did those fed MSR, irrespective of the finishing system (pasture or feedlot). In this case, we observed a differential impact of the ADG during the rainy season compared to during the dry season. The difference in ADG between the PE and MSR supplementation groups was $0.270 \mathrm{~kg}$ during the rainy season. This difference was sufficient for animals that received MSR during the rainy season to compensate for the reduced weight gain when the animals consumed more nutrients during finishing phase. However, the higher ADG during the finishing phase of these animals was not sufficient to match the time to the finishing phase of animals fed PE during the rainy season. Protein energy provided during the growing phase allows for the maintenance and/or increases the ADG during the dry season and increases the carrying capacity of a pasture during the rainy season in comparison with mineral or protein supplement (Barbero et al. 2015; Roth et al. 2013). Moreover, it reduces the finishing period as a function of the nutritional strategies of the growing phase.

Animals supplemented with PE during the rainy season were heavier (62 $\mathrm{kg}$ more) than animals receiving MSR at the beginning of the finishing phase. Mesquita et al. (2016) found that the initial $\mathrm{BW}$ in the finishing phase was negatively correlated with the daily weight gain in this period. This fact can explain the lower ADG in the finishing phase of the animals fed PE in the rainy season. In addition, increasing weight gain during the growing phase means that this phase of greater efficiency can be utilized in terms of deposited tissue, as muscle tissue deposition is higher at this stage of the growth curve (van Es 1977).

Additionally, the ADG during the rainy season was three times higher compared to growth during the dry season. When comparing the rainy season to the finishing phase, animals that were pasture-finished maintained their ADG, whereas those that were feedlot-finished had an
ADG that was two times higher. These results suggest that differences in ADG between the phases of the growth curve affect the performance more than the level of supplementation that is given within certain phases of the growth curve. Hence, the $\mathrm{BW}$ at the end of the growing phase (or the beginning of finishing phase) is as important as the feedlot ADG.

With respect to the finishing system, the use of PE on the pasture in this phase did not provoke a satisfactory performance. At the beginning of the finishing period, the BW (as a function of adult size) indicates that the animal is close to physiological maturity. At this stage, the deposition of tissues change and the animal starts to deposit more fat, increasing energy requirements (Owens et al. 1993). Pasture-finished animals had a lower ADG and backfat thickness than feedlot-finished animals. The lower energy intake limited performance at this stage of the growth curve (Meyer et al. 1965). This becomes clear when comparing carcass composition between finishing systems. Pasture-finished animals exhibited a higher proportion of muscle and lower proportion of fat than feedlot-finished animals at the end of the finishing period. It is likely that the lower concentrate-to-energy ratio in the diet of these animals reduced the production and requirement of insulin. The decrease in the circulation of insulin reduced the lipid synthesis, shifting weight gain to the deposition of muscle tissue (Keogh et al. 2015). Additionally, pasture-finished animals displayed a lower ADG and required double the amount of time to reach the slaughter weight. Animals that remained in the pasture-finishing system for a longer amount of time had an increasingly low feed conversion and reduced meat quality and restricted the area for entry of new animals (Lorenzen et al. 2007; Pavan and Duckett 2008). All of these issues lead to inefficiency in the production system, which should be avoided.

Another interesting aspect is that when slaughter is determined as a function of BW, the variable that changes according to nutritional program is the time that the animal requires to reach the predicted BW. This trend was observed for the nutritional strategies used during the growing phase. In contrast, when the two finishing systems were evaluated, a difference was observed in nearly all variables studied, even when the animals were slaughtered at the same BW. These results highlight the impact of the finishing diet on the growth curve of the animal, as differences in carcass traits are rare when animals are slaughtered at the same BW (Petit et al. 1994). In principle, this would occur because the longer finishing period would compensate for the inadequate amount of energy in pasture-finished animals.

Our results will contribute to future studies designed to further clarify divergences regarding the impact of the quantity-quality ratio of forage and supplementation during animal growth on subsequent phases. This study also serves as a basis for the investigation of other nutritional programs 
aiming to adapt nutritional strategies across the growth curve of the animal.

\section{Conclusion}

Supplementation in the dry season (under poor-quality pasture conditions) does not affect ADG during the rainy season or the finishing phase. Furthermore, while PE during the rainy season to reduce the ADG of the finishing period, the higher BW at the beginning of finishing phase is sufficient to reduce the time of the days on feed of the animals. In the same way, providing PE during the dry season to reduce the finishing period. Feedlot finishing reduces the time needed to reach slaughter weight and permits the slaughter of animals with the minimum backfat thickness recommended.

Acknowledgements We would like thank to Bellman Nutrição Animal (A Trouw Nutrition Company) and the São Paulo Research Foundation (FAPESP grant no. 2007/54850-4, grant no. 2016/01961-2, grant no. 2013/10340-3).

Compliance with ethical standards All procedures were conducted in accordance with the Brazilian Guidelines for the Care and Use of Animals for Scientific and Educational Purposes (CONCEA 2013).

Conflict of interest The authors declare that they have no conflicts of interest.

\section{References}

AOAC, 1990. Official methods of analysis, (Association of Official Analytical Chemists, Arlington).

AOAC, 1995. Official methods of analysis, (Association of Official Analytical Chemists, Arlington).

Barbero, R.P., Malheiros, E.B., Araújo, T.L.R., Nave, R.L.G., Mulliniks, J.T., Berchielli, T.T., Ruggieri, A.C. and Reis, R.A., 2015. Combining Marandu grass grazing height and supplementation level to optimize growth and productivity of yearling bulls, Animal Feed Science and Technology, 209, 110-118.

Boval, M. and Dixon, R.M., 2012. The importance of grasslands for animal production and other functions: a review on management and methodological progress in the tropics, Animal, 6, 748-762.

Cañeque, V. and Sañudo, C., 2005. Estandarización de las metodologías para evaluar la calidad del producto (animal vivo, canal, carne y grasa) en los rumiantes, (INIA: Madrid, Spain).

Carstens, G.E., 1995. Compensatory growth in beef cattle. In: Symposium of Intake by feedlot cattle. Oklahoma State University, 70-84.

Carstens, G.E., Johnson, D.E., Ellenberger, M.A.E. and Tatum, J.D., 1991. Physical and chemical components of the empty body during compensatory growth in beef steers, Journal of Animal Science, 69, 3251-3264

CONCEA. Diretriz brasileira para o cuidado e a utilização de animais para fins científicos e didáticos. In: Resolução Normativa No. 12 de 20 de Setembro de 2013. Conselho Nacional de Controle de Experimentação Animal. 2013. http://www.icmbio.gov.br/ran/ images/stories/legislacao/RESOLU\%C3\%87\%C3\%83O_
NORMATIVA_No-_12_-_20-09-2013.pdf.\%20Accessed\%2027\% 20 Oct $\% 202013$.

Detmann, E., Valente, E.E.L., Batista, E.D. and Huhtanen, P., 2014. An evaluation of the performance and efficiency of nitrogen utilization in cattle fed tropical grass pastures with supplementation, Livestock Science, 162, 141-153.

Downs, D., Erickson, G. E., Adams, D. C. and Klopfenstein, T. J., 1998. Effect of winter gain on summer rate of gain and finishing performance of yearling steers. Nebraska Beef Cattle Reports MP, 69, 6365.

Goering, H.K. and Van Soest, P.J., 1970. Forage fiber analyses, (Washington, DC: USDA).

Hankins, O.G. and Howe, P.E., 1946. Estimation of the composition of beef carcasses and cuts, (Technical Bulletin 926, Washington, DC: USDA).

Hornick, J.L., Van Eenaeme, C., Gerard, O., Dufrasne, I. and Istasse, L., 2000. Mechanisms of reduced and compensatory growth, Domestic Animal Endocrinology, 19, 121-132.

Keogh, K., Waters, S.M., Kelly, A.K. and Kenny, D.A., 2015. Feed restriction and subsequent realimentation in Holstein Friesian bulls: I. Effect on animal performance; muscle, fat, and linear body measurements; and slaughter characteristics, Journal of Animal Science, 93, 3578-3589.

Lorenzen, C.L., Golden, J.W., Martz, F.A., Grun, I.U., Ellersieck, M.R., Gerrish, J.R., and Moore, K.C., 2007. Conjugated linoleic acid content of beef differs by feeding regime and muscle, Meat Science, 75 , 159-167.

McCurdy, M.P., Horn, G.W., Wagner, J.J., Lancaster, P.A. and Krehbiel, C.R., 2010. Effects of winter growing programs on subsequent feedlot performance, carcass characteristics, body composition, and energy requirements of beef steers, Journal of Animal Science, 88, 1564-1576.

Mesquita, E.E., Castagnara, D.D., Oliveira, N.T.E., Figueiredo, A. C., Oliveira, A. C., 2016. Growth performance and carcass characteristics of Nelore Angus and Nelore Angus Guzera crossbreed cows fed with supplemented pasture during the yearling and feedlot stages, Semina: Ciências Agrárias, 37, 2701-2710.

Meyer, J.H.J., Hull, L., Weitkamp, W.H. and Bonilla, S., 1965. Compensatory growth responses of fattening steers following various low energy intake regimes on hay or irrigated pasture, Journal of Animal Science, 24, 29-37.

Minson, D.J., 1990. Forage in ruminant nutrition, (Academic Press, New York).

Moretti, M.H., Resende, F.D., Siqueira, G.R., Roth, A.P.T.P., Roth, M.T.P., Campos, W.C. and Ferreira, L.H., 2013. Performance of Nellore young bulls on Marandu grass pasture with protein supplementation, Brazilian Journal of Animal Science, 42, 438-446.

NRC, 1996. Nutrient requirements of beef cattle, (National Academy Press, Washington, DC).

Oliveira Silva, R.O., Barioni, L.G., Hall, J.A.J., Folegatti Matsuura, M., Zanett Albertini, T., Fernandes, F.A. and Moran, D., 2016. Increasing beef production could lower greenhouse gas emissions in Brazil if decoupled from deforestation, Nature Climate Change, online, DOI: 10.1038/NCLIMATE2916.

Owens, F.N., Dubeski, P. and Hanson, C.F., 1993. Factors that alter the growth and development of ruminants, Journal of Animal Science, 71, 3138-3150.

Pavan, E. and Duckett, S. K., 2008. Corn oil or corn grain supplementation to steers grazing endophyte-free tall fescue. I. Effects on in vivo digestibility, performance, and carcass quality, Journal of Animal Science, 86, 3215-3223.

Petit, H.V., Veira, D.M. and Yu, Y., 1994. Growth and carcass characteristics of beef steers fed silage and different levels of energy with or without protein supplementation, Journal of Animal Science, 52, $3221-3229$. 
Robertson, J.B. and Van Soest, P.J., 1981. The analysis of dietary fiber in food, (Marcel Dekker Press, New York).

Roth, M.T.P., Resende, F.D., Siqueira, G.R., Fernandes, R.M., Custódio, L., Roth, A.P.T.P., Moretti, M.H. and Campos, W.C., 2013. Supplementation of Nellore young bulls on Marandu grass pastures in the dry period of the year, Brazilian Journal of Animal Science, $42,447-455$.

Ryan, W.J., 1990. Compensatory growth in cattle and sheep. Nutrition abstracts and reviews (Series B), 50, 653-664.
Sainz, R.D., De La Torre, F. and Oltjen, J.W., 1995. Compensatory growth and carcass quality in growth-restricted and refed beef steers, Journal of Animal Science, 73, 2971-2979.

UNF. The 2015 Revision. In: World Population Prospects. United Nations Foundation. 2015. http://esa.un.org/unpd/wpp/ Publications/Files/Key_Findings_WPP_2015.pdf. Accessed 21 Nov 2016.

van Es, A.J.H., 1977. The energetics of fat deposition during growth, Annals of Nutrition \& Metabolim, 21, 88-104. 